Marcin BARTKOWIAK

DOI : $10.14746 / \mathrm{pp} .2019 .24 .3 .4$

Technical University of Munich, Munich, Germany

Anna RATAJCZAK

Adam Mickiewicz University in Poznań

ORCID ID: https://orcid.org/0000-0003-4823-9005

\title{
Brexit and the effects on Germany from an economic and social perspective
}

\begin{abstract}
At the end of March 2017, the British government initiated the legal procedure of withdrawal from the EU, beginning the two-year countdown towards Brexit. However, as of August 2019, the final outcome of the Brexit negotiations is still pending. The Brexit uncertainty over the years has had an impact on the UK economy negatively affecting, e.g., its growth.

This paper addresses the impact of Brexit, however from the viewpoint of Germany, focusing on the economic and social perspective. For our analyses, we differentiate between the announcement of Brexit and the possible final outcomes of Brexit. From an economic perspective, our analyses focus on the four freedoms of the European Single Market. From a social perspective, our analyses focus on mobility, studying and training in the UK, financial transactions and consumer rights. Using descriptive statistics primarily based on data from Destatis and Eurostat, we expect the following implications.

From an economic perspective, we expect negative implications like worsening trade relationship between the UK and Germany affecting jobs, especially in the automotive sector. From a social perspective, we also expect negative implications like increasing travel costs to the UK, increasing mobile phone roaming charges, additional healthcare insurance. Further areas impacted by Brexit may be studying and training in the UK, financial transactions and customers rights.
\end{abstract}

Key words: Brexit, consequences, economy, society, Germany

\section{Introduction}

"The definition of insanity is doing the same thing again and again and expecting different results... Citizens' assemblies are not about replacing MPs [Members of Parliament] and not about cancelling or giving up on parliament. They're about stopping the games that we have seen being played in this place - the horse-trading, the unicorn hunting, that have meant that we are in this gridlock" (Creasy, 2019).

This quote by Stella Creasy, Labour MP in the House of Commons in the United Kingdom (UK) since 2010 (www.parliament.uk, 2019a), concisely illustrates the process of the Brexit negotiations between the UK and the European Union (EU). Since the Brexit referendum on 23 June 2016 (GOV.UK, 2016a), no agreement has been reached so far between the negotiation parties. ${ }^{1}$ The Brexit uncertainty over the years has had an impact, in particular, on the UK economy negatively affecting its growth (FT.com, 2019). Thus, the following article addresses the impact of Brexit focusing, however, on

\footnotetext{
${ }^{1}$ The status of the Brexit negotiations refers to the 22nd of August 2019 (BBC, 2019c).
} 
Germany from an economic and social perspective. Relating thereto, we differentiate in our analyses between the announcement of Brexit and the possible executed outcomes of Brexit.

The outline of the article is as follows. First, we provide an overview about the Brexit process. Second, we outline the primary data and methods used in our analyses. Third, we analyse the economic and social impact of the Brexit referendum for Germany. Finally, we conclude.

\section{Milestones of the Brexit process}

In January 2013, in his long-awaited speech at Bloomberg London, then-Prime Minister David Cameron promised a referendum on British membership of the EU (GOV. UK, 2013). The UK's referendum and the new settlement for the UK within the EU were one of the main points of the Cameron's election campaign 2015 (Conservative Party, 2015). After the Conservatives won the general election with an outright majority in May 2015, David Cameron began convincing the European leaders to agree the proposed EU reforms (Koszel, 2018, p. 485). During the European Council meeting, on 25-26 June 2015, he also confirmed his plans for the UK's EU referendum (European Council, 2015, p. 8). In November 2015, in a letter to the President of the European Council Donald Tusk, the British Prime Minister set out the four areas of concern: economic governance, competitiveness, sovereignty and immigration (GOV.UK, 2015).

Even though, the EU leaders achieved an agreement strengthening UK's special status within the $\mathrm{EU}^{2}$ (European Council, 2016; Koszel, 2018, pp. 487-489) and the British Prime Minister suggesting to remain in the EU, $51.9 \%$ of the British voters $(17,410,742$ votes) opted for Brexit in the UK's referendum (Electoral Commission, 2016).

The leave campaign of the UK's Eurosceptic movement, building up on the problem of immigration and the costs of EU membership, triumphed in England and Wales, whereas London, Scotland and Northern Ireland voted for staying in the EU. Looking closer at British society: young people voted for remain, older, low educated people from smaller cities were in favour of Britain's exit from the EU (Arnórsson, Zoega, 2016, pp. 8-18; Zoega, 2016). Important factors influencing the UK's Brexit vote was the attitude of British citizens towards European integration and their strong sense of national identity.

Following Britain's vote to leave the EU, David Cameron announced his resignation the day after the British referendum (GOV.UK, 2016b). Theresa May, who replaced him as the new leader of the Conservatives and the Prime Minister on 13 July 2016, had to conduct the Brexit negotiations.

At the end of March 2017, the British government initiated the legal procedure of withdrawal from the EU, beginning the two-year countdown towards Brexit (European Council, 2017). In the general election, held on 8 June 2017, the Conservative party lost their parliamentary majority. 11 days later, the first round of the Brexit negotiations were initiated between the UK and the EU, in particular, focusing on: citizens' rights, financial obligations and the Northern Irish border (European Council, 2019).

\footnotetext{
${ }^{2}$ The agreement was achieved during the European Council meeting on 18-19 February 2016.
} 
After 9 months, on 19 March 2018, the amended Draft Agreement on the withdrawal of the United Kingdom of Great Britain and Northern Ireland from the European Union and the European Atomic Energy Community (Withdrawal Agreement) was published and the UK and the EU Brexit negotiators announced their goal to finalise it by October 2018 (Walker, 2019, p. 28). The final draft of the Withdrawal Agreement was agreed by the respective negotiating teams on 14 November 2018 and further considered at the extraordinary summit on 25 November 2018 (European Council, 2019). During this extraordinary meeting of the European Council, EU member states endorsed the Brexit Withdrawal Agreement and accepted the political declaration on future EU-UK relations (European Council, 2019).

The Brexit deal negotiated by the British Prime Minister and the EU leaders was rejected by the House of Commons three times in 2019 - on 15 January (202 for, 432 against - the record defeat for a sitting government in history), on 12 March (242 for, 391 against) and on 29 March (286 for, 344 against) (BBC, 2019b; www.parliament. uk, 2019b). Theresa May trying to avoid a no-deal exit was forced to ask the other EU leaders for an extension of the Article 50 of the Treaty on European Union (TEU) (first request on 20 March and further on 5 April 2019). On 10 April 2019, EU member states agreed to extend the Brexit deadline during a European Council meeting until 31 October 2019 (commonly named 'Halloween Brexit') (European Council, 2019).

Due to the ongoing Brexit negotiations, the UK was obliged to take part in the European Parliament election, which was held in Britain on 23 May 2019. Both main parties, Labour and the Conservatives, lost their representatives to the Brexit Party and the Liberal Democrats (BBC, 2019d).

The day after the European Parliament election, the British Prime Minister announced that she would resign as Conservative party leader on 7 June 2019 due to her unsuccessful Brexit negotiations. The Conservative leadership contest ended on 22 July 2019. ${ }^{3}$ Two days later, the former foreign minister and London mayor, Boris Johnson, succeeded Theresa May as new Conservative leader and as the next UK prime minister (BBC, 2019a). After his election, Boris Johnson confirmed his previous declarations and promised to deliver Brexit by 31 October 2019 (BBC, 2019a).

\section{Data and methods}

Examining the impact of Brexit on Germany from an economic and social perspective, we look at the period from 2008 to $2018 .{ }^{4}$ Our pre Brexit period includes the year 2015 as our last year due to potential effects of the Brexit referendum solidifying itself in the year 2016. ${ }^{5}$ Our analyses focus on the four freedoms of the European Single Market

${ }^{3}$ Boris Johnson gained $92,153(66.4 \%)$ votes of Conservative members, the second candidate, Jeremy Hunt, 46,656 (33.6\%). Turnout was 87.4\% among almost 160,000 eligible party members (BBC, 2019a).

${ }^{4}$ Some archived data by the Federal Statistical Office (Statistisches Bundesamt [Destatis]) dates back only to 2008. Thus, due to consistency, we set our starting point at 2008. For further information on Destatis, see https://www-genesis.destatis.de/genesis/online. If applicable, we look at data from 2008 to 2018.

5 Please note that all following interpretations on the impact of the Brexit referendum on the German economy should be treated with caution as other various factors like political decisions, monetary policy may have an impact as well. 
which are free movement of goods (Maciejewski, 2018a), workers (Kraatz, 2018), capital (Rakić, Dessimirova, 2019) and freedom of establishment and freedom to provide services (Maciejewski, 2018b). ${ }^{6}$ Further, for our analyses, we primarily use data from Destatis, Eurostat, Office for National Statistics (ONS) and Home Office. ${ }^{7}$

Due to the fact that the current status of the Brexit negotiations between the UK and the EU is not concluded (European Commission, 2019a; Government of the Netherlands, 2019), it leaves both parties with uncertainties about the extent of the access to the European Single Market for the UK. Depending on the outcome of the Brexit negotiations, whether it is going to be a soft or a hard Brexit, different scenarios remain possible (KPMG, 2017, p. 1). The German Economic Institute (Institut der deutschen Wirtschaft) elaborates four different scenarios relating to already existing relationships between the EU and other countries. The first scenario illustrates the UK as a part of the European Free Trade Association (EFTA) like Norway, Iceland and Lichtenstein (Busch, Matthes, 2016, p. 31). The second scenario reflects a relationship between the EU and the UK which is regulated by a free trade agreement and several bilateral agreements like in the case of Switzerland (Busch, Matthes, 2016, p. 32). The third scenario is a custom union between the UK and the EU like in the case of Turkey (Busch, Matthes, 2016, p. 34). For the last scenario, the relationship between the UK and the EU is regulated by the rules of the World Trade Organization (WTO) because of their membership at the WTO (Busch, Matthes, 2016, p. 36). The latter reflects a hard Brexit with no successful outcome of the negotiation process between the UK and the EU (KPMG, 2017, p. 1). In contrast to this, in a soft Brexit scenario according to Aichele, Felbermayr (2015, p. 38), the UK has a comparable status to, e.g., Norway or Switzerland and has a trade agreement with the EU. Further scenarios are possible in the means of a bespoke trade agreement and various bilateral agreements. However, because of the vast amount of possibilities, we only focus on the aforementioned four scenarios.

\section{The effects of Brexit on Germany}

\section{The economic perspective}

Analysing the impact of Brexit on Germany, we, first, begin with the economic perspective. Focusing, in particular, on the economic interdependence between the UK and Germany, we look at the economic development of Germany before and after the Brexit referendum to, respectively, get some indications about the economic impact.

The gross domestic product (GDP) of Germany for the period 2008 to 2018 ranged between 2,460 billion (bn) EUR (2009) and 3,386 bn EUR (2018) and has been steadily

${ }^{6}$ See also Article 26(2) of the Treaty on the Functioning of the European Union (TFEU). For detailed definitions on the free movement of goods, free movement of workers, Freedom of establishment and freedom to provide services as well as free movement of capital see Maciejewski (2018a), Kraatz (2018), Maciejewski (2018b) and Rakić, Dessimirova (2019) respectively.

${ }^{7}$ For further details on Eurostat see https://ec.europa.eu/eurostat/data/database; on ONS see https:// www.ons.gov.uk/ and on Home Office see https://www.gov.uk/government/statistics. If applicable, we look at data from Eurostat from 2008 to 2018. 
increasing from 2009. Between 2009 and 2018 the percentage of the German GDP on the EU-28 GDP ranged from $19.95 \%$ (2009) to $21.31 \%$ (2018). During this period, Germany has been the leading economy in the EU. ${ }^{8}$

Free movement of goods ${ }^{9}$

To begin with the implications of Brexit on the trade relationship and, thus, on the free movement of goods, between the UK and Germany, Figure 1 illustrates the total value of exports from Germany to the UK as well as the respective percentage of the total amount of exports from Germany for the period 2008 to 2018. The first thing to be noticed is the drop of exports in 2009 which is related to the global financial crisis (Federal Ministry of Finance, 2009) (Bundesministerium für Finanzen). From 2008 to 2015, the total amount of exports from Germany to the UK ranges between $53.24 \mathrm{bn}$ EUR (2009) and 89.02 bn EUR, which reflects the peak in 2015. We get an average yearly increase of $9.02 \%$ from 2009 to 2015 excluding the decrease from 2008 to 2009 due to the confounding effect of the global financial crisis. From 2016 to 2018 the total amount of exports from Germany to the UK ranges between 82.04 bn EUR (2018) and

Figure 1. Total value of exports from Germany to the United Kingdom and the respective percentage of total German exports from 2008 to 2018

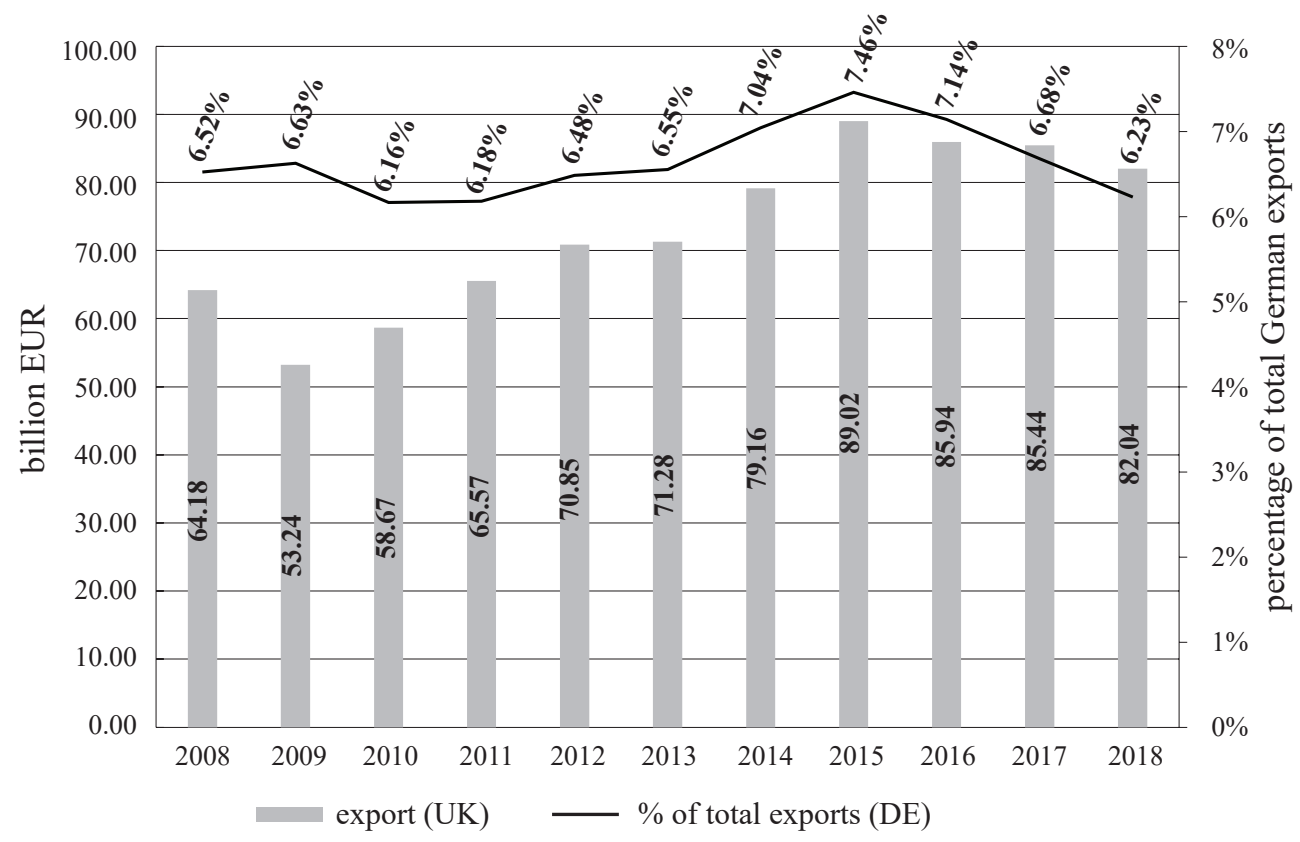

Source: Own representation based on data from Destatis.

\footnotetext{
${ }^{8}$ Data was retrieved from Destatis and Eurostat.

9 The free movement of goods is governed by Articles 28-37 TFEU.
} 
85.94 bn EUR (2016) with an average yearly decrease of $-2.67 \%$ from 2015 to 2018. If we put the total value of exports to the UK in relation to the total amount of exports from Germany ranging between 803.31 bn EUR (2009) and 1.32 trillion (tn) EUR (2018) from 2008 to 2018 , we get a range between $6.16 \%$ and $7.46 \%$. For Germany, the UK is an important trade partner reflected in its third or fourth position as the country with the highest amount of total exports from Germany between 2008 and 2017. However, in 2018 the UK falls back to fifth position. Further, we see on average a decrease of 0.41 percentage points on the share of German exports to the UK from 2015 to 2018 . The trading good with the highest export volume from Germany to the UK is "automobiles and parts" followed by "machinery"10 for all years between 2008 and 2018. This implies that the automotive industry is potentially affected the most in a case of worsening trade relationship with the UK. ${ }^{11}$

Figure 2 illustrates the total value of imports from the UK to Germany as well as the respective percentage of the total amount of imports to Germany from 2008 to 2018. From 2008 to 2015, the total amount of imports from the UK to Germany ranges between 32.45 bn EUR (2009) and 44.74 bn EUR (2011). We get an average yearly increase of $3.34 \%$ from 2009 to 2015 excluding the decrease from 2008 to 2009 due to the confounding effect of the global financial crisis. From 2016 to 2018 the total

Figure 2. Total value of imports from the United Kingdom to Germany and the respective percentage of total German imports from 2008 to 2018

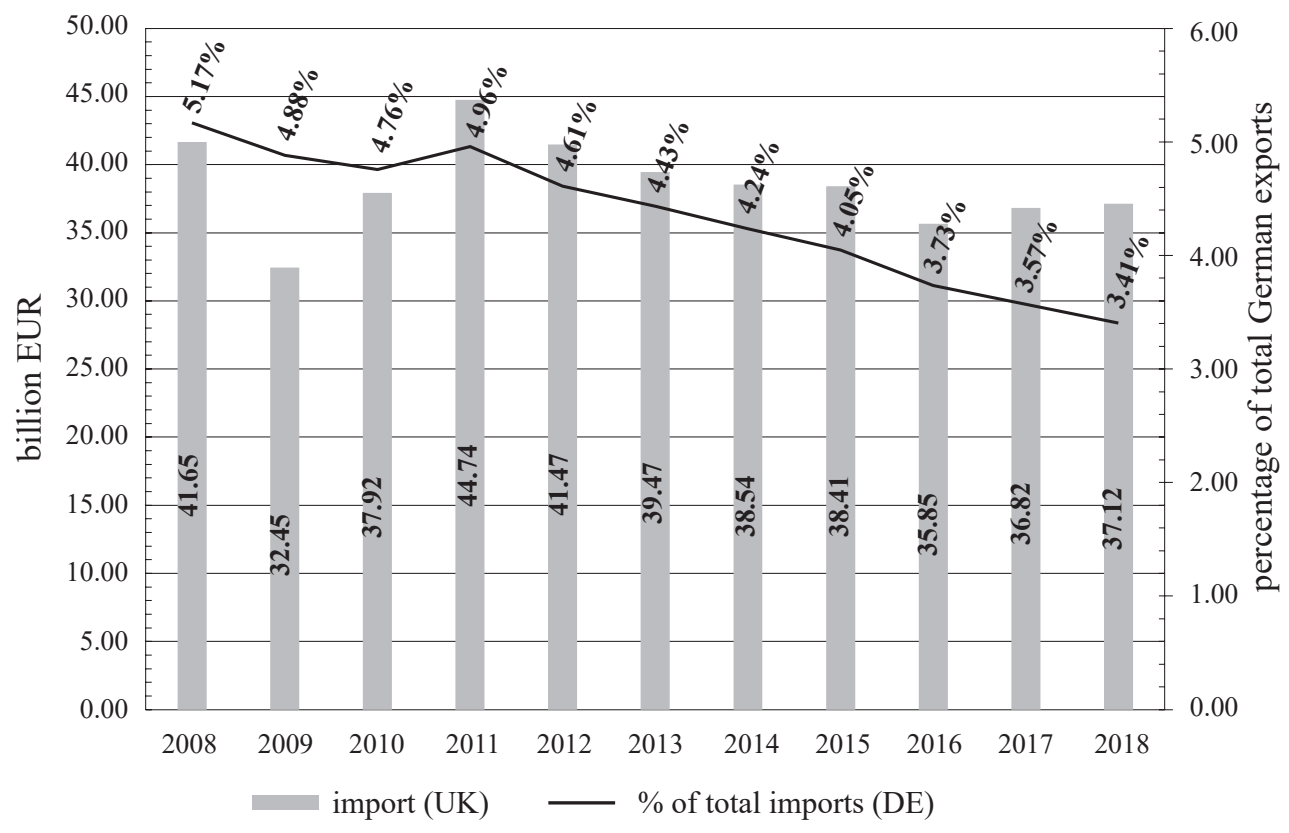

Source: Own representation based on data from Destatis.

${ }^{10}$ The trading goods are classified according to GP 2019. For further details, see Destatis (2018, pp. 1-553).

${ }^{11}$ If not stated otherwise, all data for the analysis is extracted from Destatis. 
amount of imports from the UK to Germany ranges between 35.65 bn EUR (2016) and 37.12 bn EUR (2018) with an average yearly decrease of $-1.04 \%$ from 2015 to 2018 . If we put the total value of imports from the UK in relation to the total amount of imports to Germany ranging between 664.61 bn EUR (2009) and 1.09 tn EUR (2018) from 2008 to 2018 , we get a range between $3.41 \%$ and $5.17 \%$. In the ranking of countries with the highest amount of total imports to Germany, the UK falls back from sixth to ninth position from 2008 to 2015 . From 2016 to 2018 the UK takes eleventh position. Further, we see on average a decrease of 0.21 percentage points on the share of imports from the UK for the period 2015 to 2018. The trading good with the highest import volume from the UK is "automobiles and parts" for the years 2013 to 2018, "crude oil and natural gas" for the years 2008 and 2010 to 2012 and "chemicals" for 2009. Again, this implies that the automotive industry is potentially affected the most in the case of worsening trade relationship with the UK. ${ }^{12}$

In general, the German economy is highly dependent on exports highlighted by the fact that almost every fourth workplace is related to exports (Federal Agency for Civic Education, 2019) (Bundeszentrale für politische Bildung). As an example, the foreign trade quota ${ }^{13}$ for Germany was $70.8 \%$ in 2017 emphasizing the importance of foreign trade for Germany (Federal Agency for Civic Education, 2019) and, thus, making it vulnerable to worsening trade relationships.

Depending on the four aforementioned scenarios, we get different potential effects on the free movement of goods. If the UK decides to join the European Economic Area (EEA), they remain in the European Single Market. As a result, the principle of free movement of goods applies. However, the integration with the EU is less in-depth, e.g., the EEA does not have EU common trade policy. Further, the UK will lose its influence in the European Parliament as well as its influence on the rules of the European Single Market (Busch, Matthes, 2016, p. 31).

For the second scenario, the free movement of goods is restricted and depends on the negotiated free trade agreement with the EU (Busch, Matthes, 2016, pp. 32, 74). If the UK enters a customs union with the EU, the free movement of goods will partially be restricted depending on the negotiated terms of the customs union with the EU (Busch, Matthes, 2016, pp. 34, 74). For the last scenario, which is a hard Brexit scenario, the free movement of goods does not apply. The limited access to the EU market will be given by the WTO membership of the UK (Busch, Matthes, 2016, pp. 36, 74).

Looking at the consequences for the German economy, it has to be expected that any worsening trade relationship is going to negatively affect the economic growth of Germany as trade with the UK is of macroeconomic importance (Felbermayr et al., 2017, pp. 84-85). Recently, the Association of German Chambers of Commerce and Industry (Deutscher Industrie- und Handelskammertag [DIHK]) conducted a survey among companies in Germany with business relationships to the UK. Based on about 1,500 replies, they find that $71 \%$ are expecting business getting worse, especially in the automotive industry and retail trade (DIHK, 2019, p. 4). Further, 78\% fear a customs bureaucracy after the Brexit, followed by higher tariff barriers regarding trade with $57 \%$ and legal uncertainty with $45 \%$ (DIHK, 2019, p. 7).

${ }^{12}$ If not stated otherwise, all data for the analysis is extracted from Destatis.

13 The foreign trade quota is defined as the sum of the total amount of exports and imports of a country divided by its respective GDP. 


\section{Free movement of workers ${ }^{14}$}

Figure 3 illustrates the number of British citizens employed in Germany and the number of German citizens employed in the UK from 2008 to 2017. For German citizens employed in the UK, we see a steady increase in the number of workers from 2008 to 2013 followed by a steady decrease in 2014 and 2015. From 2016 to 2017 we see, again, a steady increase in the number of German citizens employed in the UK. For British citizens employed in Germany, we see an up and down movement from 2008 to 2017. As there are more German citizens employed in the UK than vice versa, German citizens will be more affected, especially in the case of a hard Brexit. Further, we detect no indication on the negative impact of the Brexit referendum as the number of German citizens employed in the UK increases from 2016. In contrast to, the number of British citizens employed in Germany slightly decreases from 2016.

Figure 3. Number of persons employed by nationality from 2008 to 2017

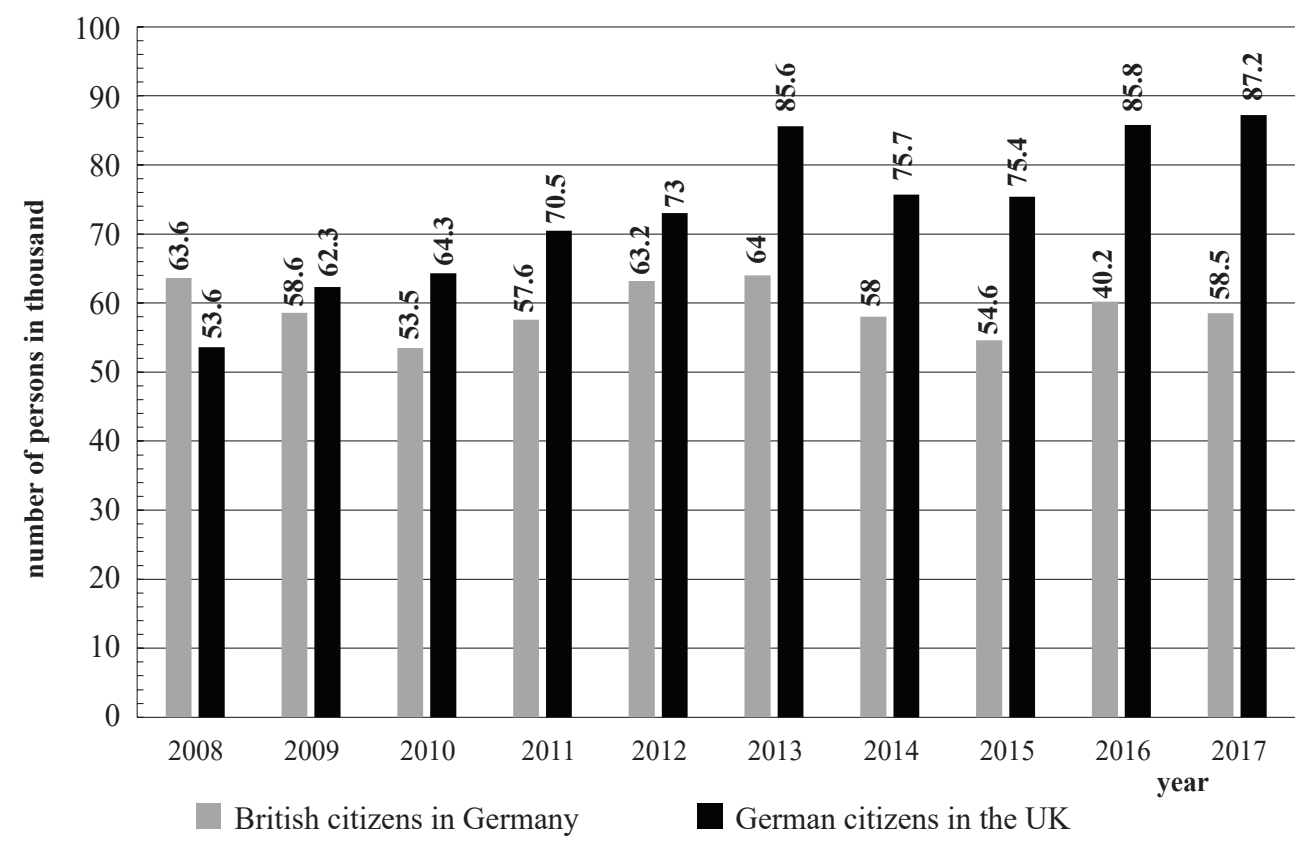

Source: Own representation based on Destatis (2019).

Having a closer look at the consequences on the free movement of workers depending on our aforementioned scenarios, the free movement of workers exists in the first scenario as the UK stays in the EU internal market if joining the EEA (Busch, Matthes, 2016, pp. 31, 74). For the second scenario, free movement of workers may be restricted. However, the extent of the free movement of workers depends on the final negotiated bilateral agreements between the UK and the EU (Busch, Matthes, 2016, pp. 32, 74).

\footnotetext{
${ }^{14}$ The free movement of workers is governed by Articles 45-48 TFEU.
} 
The third and fourth scenario results in no free movement of workers (Busch, Matthes, 2016, pp. 35, 36, 74).

Restricting the free movement of workers between the UK and the EU may result in a shift of migration streams to countries like Germany (Brücker, Vallizadeh, 2016, p. 7) potentially containing skilled workers having a positive effect on, e.g., the economic growth and innovation in Germany (Federal Ministry for Economic Affairs and Energy, 2019) (Bundesministerium für Wirtschaft und Energie). However, the Halle Institute of Economic Research (Leibniz-Institut für Wirtschaftsforschung Halle) estimates that at least 100,000 jobs will be affected in the case of a hard Brexit in Germany (Brautzsch, Holtemöller, 2019, p. 4), especially in the automotive industry counting about 15,000 jobs (Brautzsch, Holtemöller, 2019, p. 7).

Figure 4. Unemployment rate in Germany by age group from 2008 to 2018

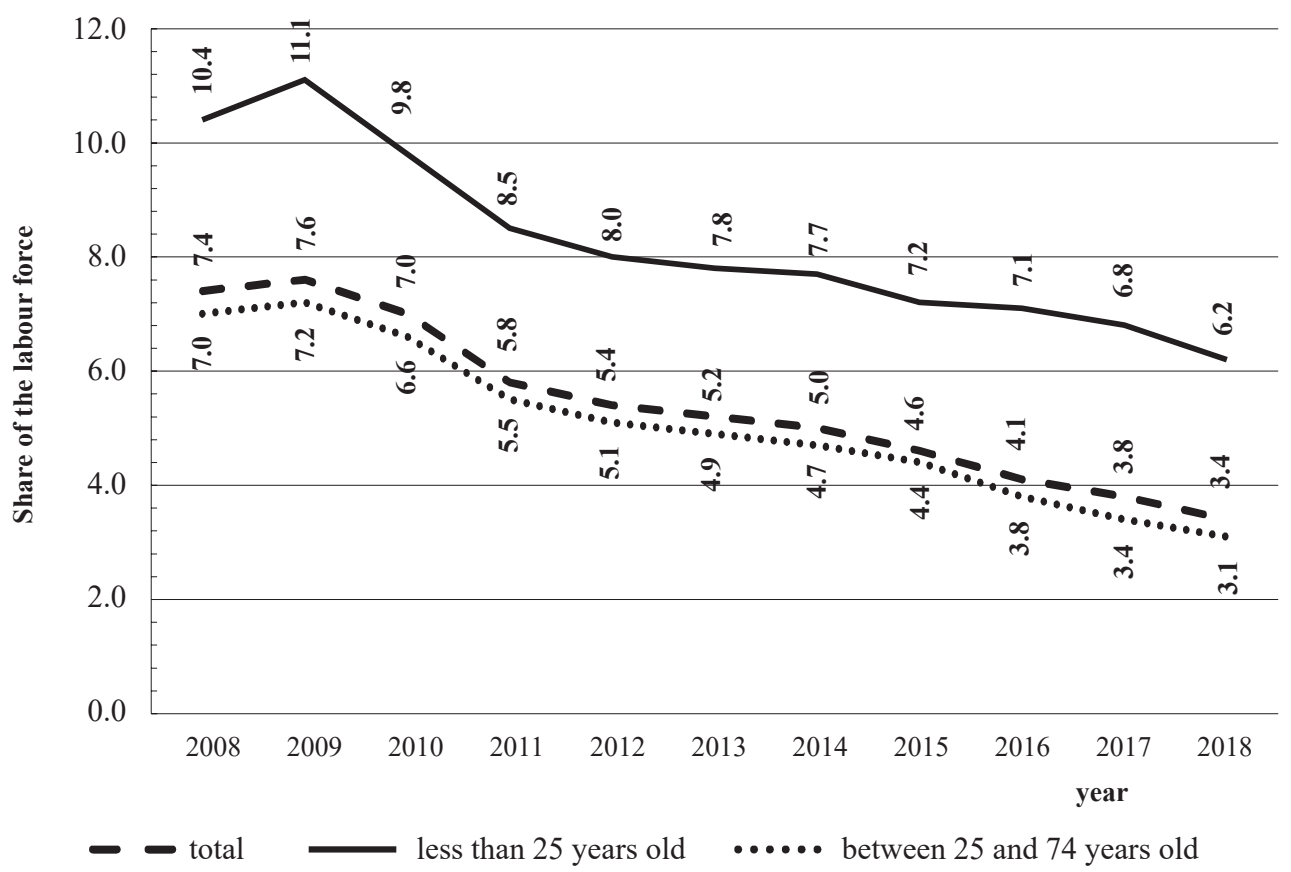

Source: Own representation based on data from Destatis. See also Destatis (2019).

Looking at Figure 4 at the unemployment rate ${ }^{15}$ of Germany from 2008 to 2018, we see a steady decline of the unemployment rate except for 2009 potentially due to the global financial crisis. The development of the unemployment rate of Germany, especially from 2016 to 2018, does not indicate that the result of the Brexit referendum has a noticeable impact on the unemployment rate.

${ }^{15}$ The unemployment rate of Germany is defined as "[...] the number of people unemployed as a percentage of the labour force" (Eurostat, 2018). 
Freedom of establishment and freedom to provide services ${ }^{16}$

Figure 5 illustrates the trade in services between the UK and Germany. Trade in services includes, for instance, financial services like insurance (Busch, Matthes, 2016, pp. 32-33) or tourism (Barth, 1999, p. 11). Import of services from the UK to Germany ranged between 15.87 bn EUR (2010) and 24.80 bn EUR (2017) steadily increasing from 2010 to 2017. Export of services from Germany to the UK ranged between 18.28 bn EUR (2010) and 24.84 bn EUR (2017) having, overall, a positive trend from 2010 to 2017. Overall, the results of the Brexit referendum do not indicate a negative impact on trade in services between the UK and Germany.

Figure 5. Trade in services with the United Kingdom from a German perspective from 2010 to 2017

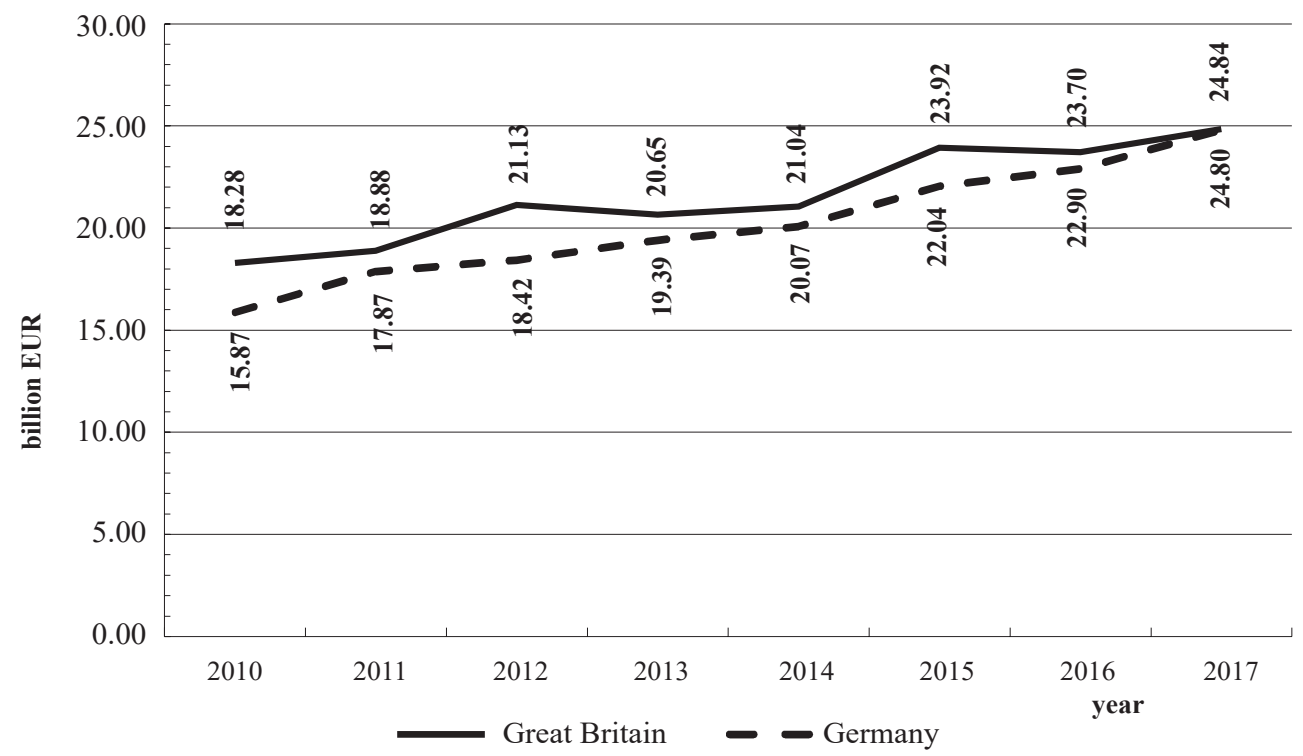

Source: Own representation based on data from Eurostat. See also (Felbermayr et al., 2017).

With regard to our scenarios, the first one has no restrictions on the free movement of services (Busch, Matthes, 2016, pp. 31, 74). For the second scenario, the extent of the free movement of services depends on the negotiated bilateral agreement between the UK and the EU (Busch, Matthes, 2016, pp. 32, 33, 74). The third and fourth scenario, again, results in no free movement of services (Busch, Matthes, 2016, pp. 35, 36, 74). Relating thereto, the General Agreement on Trade in Services (GATS) of the WTO applies (Busch, Matthes, 2016, pp. 25, 26, 36, 74).

As the UK is especially strong in the financial service sector, the consequence for this sector are likely to be severe (Busch, Matthes, 2016, p. 25). Because of pending Brexit negotiations, regulatory uncertainties remain referring, e.g., to financial markets (Deutsche

${ }^{16}$ The freedom of establishment and freedom to provide services is governed by Articles 49-55 TFEU and Articles 56-62 TFEU. 
Börse Group, 2018, p. 2). This may be a trigger of relocation of financial services from the City of London to, for instance, Frankfurt (Busch, Matthes, 2016, p. 27) via, e.g., subsidiaries to have access to the European Single Market (Deutsche Börse Group, 2018, p. 3 ).

\section{Free movement of capital ${ }^{17}$}

Figure 6 illustrates the bilateral foreign direct investments (FDIs) ${ }^{18}$ being one figure indicating the movement of capital for Germany as well as for the UK. Except for 2009, we see a steady increase in the amount of investments in the UK by German investors from 2008 (87.48 bn EUR) to 2015 (139.13 bn EUR). However, from 2016 the amount of FDIs decreases from 133.07 bn EUR (2016) to 124.39 bn EUR (2017). In contrast to this, the UK has overall a lower FDI compared to Germany from 2008 to 2017 ranging between 24.17 bn EUR (2015) and 32.07 bn EUR (2008). The decrease of German FDIs from 2016 may be a precaution of investors pulling back its investments because of the Brexit referendum related to a substantial amount of uncertainty about the outcome of the Brexit negotiations thereto (Busch, Matthes, 2016, p. 74).

Similarly to the free movement of services, the first scenario guarantees the free movement of capital. For the second, third and fourth scenarios, the free movement of capital is not guaranteed (Busch, Matthes, 2016, pp. 35, 36, 74).

Figure 6. Bilateral FDI of Germany and the United Kingdom from 2008 to 2017

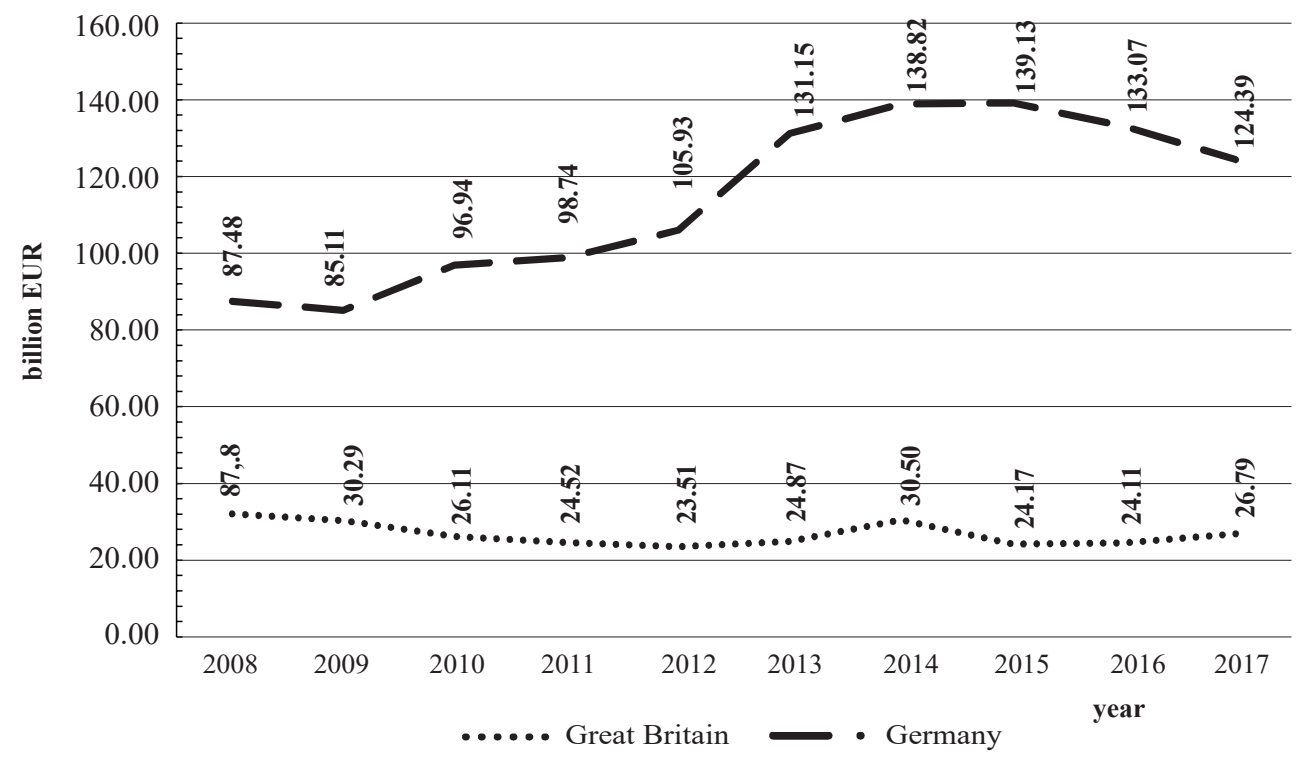

Source: Own representation based on data from Eurostat.

17 The free movement of capital is governed by Articles 63-66 TFEU.

${ }^{18}$ FDI is defined as the amount of investments made by an investor in one country in a company in another country having the goal of obtaining some substantial influence ( $\geq 10 \%$ of outstanding shares or voting rights of the respective company) (Eurostat, 2019). 
The social perspective

The UK's Brexit decision is not only limited to economic consequences. It may also affect German citizen's everyday life. In the following, we discuss the social impact of the UK's divorce referendum, in particular, taking into account the implications of a hard Brexit for German travellers and consumers.

To begin with, we briefly outline the general issues concerning the number of German citizens living in the UK and vice versa and the number of naturalization of British and German citizens in both countries.

From 2010 to 2018, the total number of German citizens in the UK ranged between 114,138 (2010) and 155,780 (2018). For comparison, the number of UK citizens living in Germany for the period 2010 to 2018, ranged between 96,143 (2010) and 106,155 (2018) and has been steadily increasing until $2017(116,465) .{ }^{19}$

Moreover, if we look at German citizens acquiring UK citizenship, we see a steady increase from $2015(584)$ to $2018(4,759)$. The highest growth has been recorded in the years after the Brexit referendum - in $2017(2,636)$ and 2018. ${ }^{20}$

We also observe an increase in the number of British citizens becoming German from 2016 to 2017 which is illustrated by figure 7 showing the total number of naturalizations of British citizens in Germany by age group from 2008 to 2018. In the year of the Brexit referendum 2016, we see an increase of naturalizations of British citizens by $360.61 \%$.

Figure 7. Total number of naturalization of British citizens in Germany by age group from 2008 to 2018

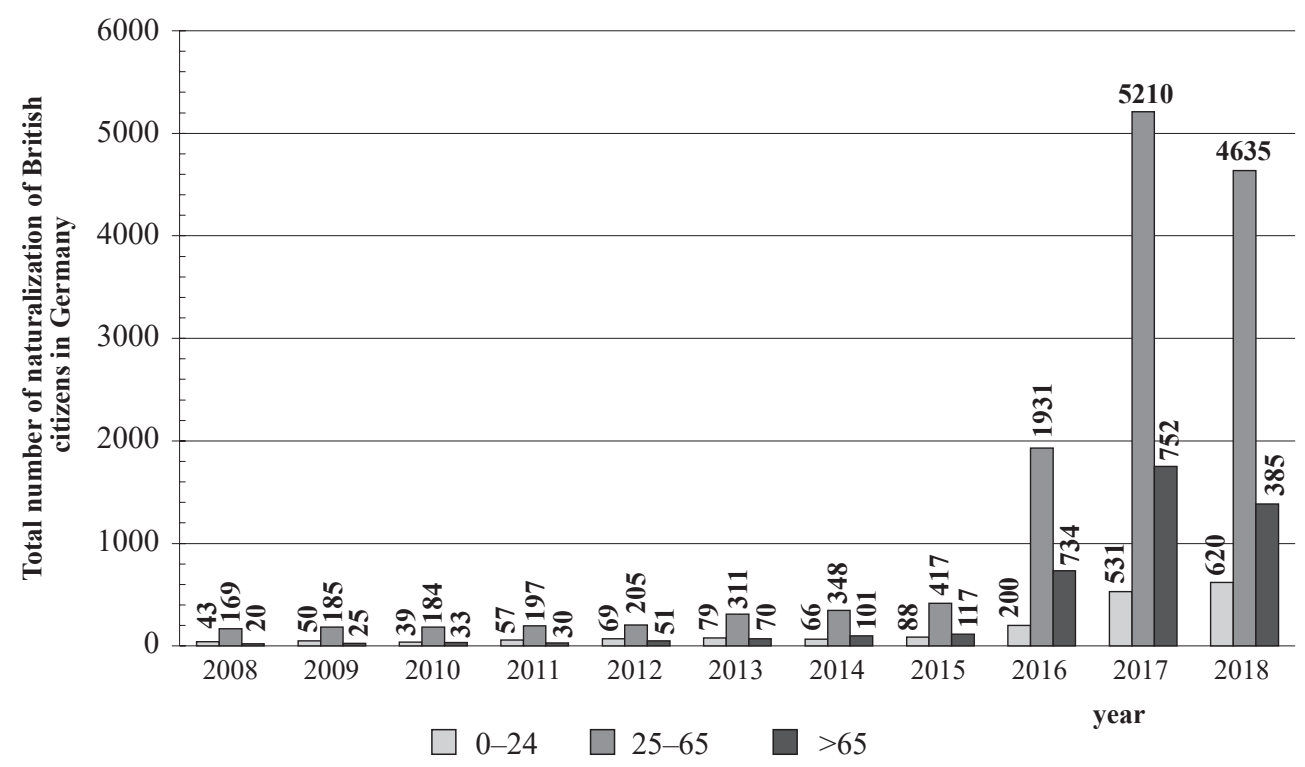

Source: Own representation based on data from Destatis.

19 Data was retrieved from Destatis (see also Destatis (2019)) and ONS.

${ }^{20}$ Data was retrieved from Destatis (see also Destatis (2019)) and Home Office. 
In 2017, we see an increase in the number of UK citizens applying for German citizenship by $161.53 \%$. In 2018 , we see a decline of applications by $-11.38 \%$. We see major changes for the age group of people between 25-65 suggesting uncertainty among UK citizens potentially caused by the Brexit decision. ${ }^{21}$

Turning to the possible Brexit repercussions on German citizens, we focus on areas such as mobility (border checks, passports, visas, as well as healthcare and mobile charges), studying and training in the UK and other issues (financial transactions and consumer rights).

\section{Mobility}

The UK is entitled under the Treaties to exercise border controls on persons and not to participate in the Schengen area (Protocol No. 20) (European Council, 2016, p. 10). Until the final UK's EU withdrawal, EU citizens are allowed to enter the UK with a valid identity card or passport. According to the EU Commission proposal, British citizens do not need a visa for short stays (90 days) after Brexit within the EU if the same applies to EU citizens (European Consumer Centre Germany [ECCG], 2019) (Europäisches Verbraucherzentrum Deutschland).

Looking at further implications of the UK withdrawal from the EU on German travellers, we can expect, e.g.: lower additional holiday costs, if the Pound depreciates against the EUR due to Brexit; increasing travel costs, especially in air travel due to higher airport charges and partial restriction of passenger rights on flights to or from the UK (Hauck \& Aufhäuser Privatbankiers AG, 2019).

The EU Regulations concerning flight delays, flight cancellations and overbooked flights will apply for flights from EU cities like Munich (Germany). They will apply for flights from the UK to the EU only if the airline is headquartered in an EU member state (ECCG, 2019).

In addition, the current rail passenger rights (Eurotunnel is a British-French joint venture), as well as ferry and bus passenger rights continue to apply even after Brexit (ECCG, 2019).

Further, when travelling within the EU, as well as to Iceland, Norway, Switzerland and Liechtenstein, it is not necessary to buy additional travel insurance. The European Health Insurance Card (EHIC) ensures EU citizens access to stateprovided healthcare, while temporarily staying in any of these countries. In the case of a hard Brexit, the EHIC will no longer be valid in the UK. However, if the UK remains a member of the EEA, EU citizens will be able to use it for medical treatment (ECCG, 2019).

Moreover, as of now, mobile network operators are bound by EU roaming rules meaning that, e.g., mobile communication services in the UK may be used for the same costs as in Germany (European Commission, 2019b; Federal Foreign Office, 2019). Following the UK exit from the EU, operators may impose additional costs for travellers using roaming services (European Commission, 2019b).

\footnotetext{
${ }^{21}$ Data was retrieved from Destatis.
} 
Under EU rules on free movement, EU students studying in another EU member state have the same access to higher education and the same right to fee support as local students (Bolton, Hubble, 2019, p. 16). According to the Higher Education Student Statistics, in 2017/2018 139,150 students studying at UK universities were from the EU (HESA, 2019). ${ }^{22}$ After the UK referendum, the number of first year students from other EU member states decreased but was still higher than in 2013/2014 (HESA, 2019).

In 2017/2018, Germany was the third EU country (after Italy and France) sending students to the UK $(13,545$ student enrolments). Germany was also the top EU country to send students to Wales and Scotland (HESA, 2019).

In 2016, 31,243 students came to the UK by means of the Erasmus+ programme (from Germany 5,258). In 2016/2017, Germany was the third most popular host country for UK students and trainees $(2,317)$ (European Commission, 2018). Future participation in Erasmus+ programme will depend on a deal or a no-deal Brexit (Bolton, Hubble, 2019, pp. 18-20).

\section{Financial transactions}

Having a closer look at financial transactions, Brexit may affect cash investments, as well as payment transactions from and to the UK, e.g., pension payments or school fee payments (Hauck \& Aufhäuser Privatbankiers AG, 2019). Further, Brexit may also affect installments on loans in pounds due to changes in currency exchange rates (Hauck \& Aufhäuser Privatbankiers AG, 2019). Moreover, EU consumers will still be able to make cross-border payments in EUR, using SEPA (Single Euro Payments Area) payments (ECCG, 2019).

\section{Consumer rights}

Looking at consumer rights, after a-no deal Brexit, EU consumer law will be applicable under certain circumstances, e,g., in the case of buying goods from a shop or website in the UK or suing a UK-based trader before a court in an EU member state (European Commission, 2019c). In those cases, EU consumer law will apply, if the UK trader directs his/her commercial activities in an EU member state of consumer's residence (European Commission, 2019c), e.g., if the UK trader directs his/her commercial activities to German consumers. Further, in an event of a no-deal Brexit import tariffs and other indirect taxes may apply for goods from the UK (European Commission, 2019c).

\section{Summary}

This article analyses the consequences of Brexit on Germany from an economic as well as social perspective. From an economic perspective, we potentially find negative implications like worsening trade relationship between the UK and Germany affecting jobs, espe-

22 It represents $6 \%$ of all EU students studying in the UK ( $80 \%$ of students were from the UK, $14 \%$ were from countries outside the EU) (HESA, 2019). 
cially in the automotive sector, and GDP in Germany. However, an opportunity may arise in the financial service sector, e.g., for the city Frankfurt in Germany, to have access to the European Single Market. Further, we also see a decline in German direct investments in the UK after the Brexit referendum reflecting the uncertainty of the final Brexit outcome.

From a social perspective, we also expect negative implications like travelling to the UK, e.g., increasing travel costs (especially in air travel), partial restriction of passenger rights on flights to or from the UK, increasing mobile phone roaming charges, additional healthcare insurance. Further areas impacted by Brexit may be studying and training in the UK (e.g., access to higher education, fee support), financial transactions (e.g., cash investments and payments transactions) and customers rights (e.g., more expensive import goods from the UK). However, the actual consequences of Brexit for Germany remain to be seen.

August 2019

\section{Bibliography}

Aichele R., Felbermayr G. (2015), Kosten und Nutzen eines Austritts des vereinigten Königreichs aus der Europäischen Union, Bertelsmann Stiftung, https://www.bertelsmann-stiftung.de/filead$\mathrm{min} /$ files/BSt/Publikationen/GrauePublikationen/BREXIT_DE.pdf, 22.06.2019.

Arnórsson Á., Zoega G. (2016), On the causes of Brexit, http://hdl.handle.net/10419/147310, 19.06.2019.

Barth D. (1999), The Prospects of International Trade in Services, Friedrich Ebert Foundation, Bonn, https://library.fes.de/pdf-files/stabsabteilung/00524.pdf, 04.07.2019.

BBC (2019a), Boris Johnson wins race to be Tory leader and PM, 23.07.2019, https://www.bbc.com/ news/uk-politics-49084605, 20.08.2019.

BBC (2019b), Brexit: Your simple guide to the UK leaving the EU, 21.05.2019, https://www.bbc.com/ news/uk-46318565, 19.06.2019.

BBC (2019c), News: UK. Brexit, 22.08.2019, https://www.bbc.com/news/politics/uk_leaves_the_eu, 22.08.2019.

BBC (2019d), The UK's European elections 2019, 06.2019, https://www.bbc.com/news/topics/ crjeqkdevwvt/the-uks-european-elections-2019, 19.06.2019.

Brautzsch H.-U., Holtemöller O. (2019), Potential International Employment Effects of a Hard Brexit (Discussion Papers No. 4), Halle Institute for Economic Research, https://www.iwh-halle.de/ fileadmin/user_upload/publications/iwh_discussion_papers/iwh-discussion-paper_2019-04_ Brautzsch_Holtemoeller.pdf, 03.07.2019.

Brücker H., Vallizadeh E. (2016), Brexit: Mögliche Folgen für die Arbeitnehmerfreizügigkeit und die Arbeitsmigration (Aktuelle Berichte No. 16), Institute for Employment Research, http://doku. iab.de/aktuell/2016/aktueller_bericht_1616.pdf, 01.07.2019.

Busch B., Matthes J. (2016), Brexit - the economic impact: A meta-analysis, http:/hdl.handle. net/10419/157171, 29.04.2019.

Conservative Party (2015), 2015 Conservative Party Manifesto, 14.04.2015, https://www.conservatives.com/manifesto2015, 19.06.2019.

Creasy S. (2019), MPs'best quotes from the Brexit debate, 29.01.2019, https://www.theguardian.com/ politics/2019/jan/29/mps-best-quotes-from-the-brexit-debate, 09.07.2019.

Destatis (2018), Güterverzeichnis für Produktionsstatistiken, https://www.destatis.de/DE/Methoden/ Klassifikationen/Gueter-Wirtschaftsklassifikationen/Downloads/gueterverzeichnis-32002011 99004.pdf?_blob=publicationFile\&v=4, 27.06.2019. 
Destatis (2019), Brexit Monitor, https://www.destatis.de/Europa/DE/Thema/Brexit/Brexit_Aktuell. html?nn=240498\#arbeitsmarkt, 30.06.2019.

Deutsche Börse Group (2018), The Brexit process and its impact on financial markets, Frankfurt/ Main, https://deutsche-boerse.com/resource/blob/149080/69d3a700fcb63274fb25ba4d2c 213f98/data/brexit-process-december2018.pdf, 04.07.2019.

DIHK (2019), The Impact of Brexit on German Businesses: Results of the IHK Business Survey: Going International 2019, https://www.google.com/url?sa=t\&rct=j\&q=\&esrc=s\&source $=$ web\&cd=4\&ved=2ahUKEwiqirDB1YDjAhVUiFwKHeXyBjcQFjADegQIAhAC\&url= https $\% 3 \mathrm{~A} \% 2 \mathrm{~F} \% 2 \mathrm{Fwww}$.dihk.de\%2Fressourcen\%2Fdownloads\%2Fbrexit-umfrage-02-19eng.pdf\&usg=AOvVaw3lpLkv21HLICGrhqNVJd5H, 29.04.2019.

ECCG (2019), Der Brexit und seine Folgen für Verbraucher, 05.2019, https://www.evz.de/de/verbraucherthemen/der-brexit-und-seine-folgen-fuer-verbraucher/, 29.06.2019.

Electoral Commission (2016), EU referendum results, 23.06.2016, https://www.electoralcommission. org.uk/find-information-by-subject/elections-and-referendums/past-elections-and-referendums/eu-referendum/electorate-and-count-information, 19.06.2019.

European Commission (2018), Erasmus + annual report 2017: Statistical annex. Erasmus ${ }^{+}$programme annual report 2017, Publications Office of the European Union, Luxembourg, https:// publications.europa.eu/en/publication-detail/-/publication/519aa03d-1 f0b-11e9-8d04-01aa75ed71a1, 21.07.2019.

European Commission (2019a), 'No-deal' Brexit: European Commission takes stock of preparations ahead of the June European Council (Article 50), http://europa.eu/rapid/press-release_IP-192951_en.htm, 18.06.2019.

European Commission (2019b), Travelling between the UK and the EU in the the event of "no deal", https://ec.europa.eu/info/sites/info/files/factsheet_1_travel_en_final.pdf, 20.07.2019.

European Commission (2019c), Consumer rights in the event of "no deal", https://ec.europa.eu/info/ sites/info/files/factsheet-consumer-rights-no-deal_en.pdf, 20.07.2019.

European Council (2015), European Council meeting (25 and 26 June 2015) - Conclusions (No. EUCO 22/15), https://www.consilium.europa.eu/media/21717/euco-conclusions-25-26june-2015.pdf, 19.06.2019.

European Council (2016), European Council meeting (18 and 19 February 2016) - Conclusions (No. EUCO 1/16), https://www.consilium.europa.eu/media/21787/0216-euco-conclusions.pdf, 19.06.2019.

European Council (2017), The Article 50 notification letter (No. XT 20001/17), http://data.consilium. europa.eu/doc/document/XT-20001-2017-INIT/en/pdf, 19.06.2019.

European Council (2019), Brexit: Timeline, 21.06.2019, https://www.consilium.europa.eu/en/policies/ eu-uk-after-referendum/, 21.06.2019.

European Parliament (2019), 2019 European election results, 05.06.2019, https://election-results.eu/ national-results/united-kingdom/2019-2024/, 17.07.2019.

Eurostat (2018), Unemployment - LFS adjusted series (une): Reference Metadata in Euro SDMX Metadata Structure (ESMS) Compiling agency: Eurostat, the statistical office of the European Union, https://ec.europa.eu/eurostat/cache/metadata/en/une_esms.htm, 02.07.2019.

Eurostat (2019), Foreign direct investments, https://ec.europa.eu/eurostat/web/structural-business-statistics/global-value-chains/fdi, 02.07.2019.

Federal Agency for Civic Education (2019), Entwicklung des deutschen Außenhandels: Export, Import und Exportüberschuss in absoluten Zahlen, 1995 bis 2018, https://www.bpb.de/ wissen/4OHFAY, 28.06.2019.

Federal Foreign Office (2019), Prepared for any eventuality - how the German Government is getting ready for Brexit, 16.04.2019, https://www.auswaertiges-amt.de/en/aussenpolitik/europa/Brexit/ brexit-preparedness?openAccordionId=item-2208434-9-panel,\%2030.09.2019, 30.09.2019. 
Federal Ministry for Economic Affairs and Energy (2019), Fachkräfte für Deutschland, https://www. bmwi.de/Redaktion/DE/Dossier/fachkraeftesicherung.html, 03.07.2019.

Federal Ministry of Finance (2009), Die Wirtschafts- und Finanzkrise - Konjunktur und strukturpolitische Antworten ausgewählter Volkswirtschaften, https://www.bundesfinanzministerium.de/Content/DE/Monatsberichte/2009/08/Artikel/analysen-und-berichte/b06finanzkrise-antworten/finanzkrise-antworten.html; jsessionid=EC3188D3D347AF2 B35A8710EC4F4C60C\#doc38796bodyText2, 27.06.2019.

Felbermayr G., Gröschl J., Heiland I., Braml M., Steininger M. (2017), Ökonomische Effekte eines Brexit auf die deutsche und europäische Wirtschaft, ifo Institut, https:/www.bmwi.de/ Redaktion/DE/Publikationen/Studien/oekonomische-effekte-eines-brexit-auf-die-deutschewirtschaft.pdf?_blob=publicationFile \&v $=6,29.04 .2019$.

FT.com (2019), Brexit uncertainty is costing the UK dearly, 15.02.2019, https:/www.ft.com/content/ cb298576-3116-11e9-8744-e7016697f225, 12.07.2019.

GOV.UK (2013), EU speech at Bloomberg: Prime Minister David Cameron discussed the future of the European Union at Bloomberg, 23.01.2013, https:/www.gov.uk/government/speeches/euspeech-at-bloomberg, 19.06.2019.

GOV.UK (2015), EU reform: PM's letter to President of the European Council Donald Tusk, 10.11.2015, https://assets.publishing.service.gov.uk/government/uploads/system/uploads/attachment_data/ file/475679/Donald_Tusk_letter.pdf, 19.06.2019.

GOV.UK (2016a), EU referendum, 24.06.2016, https://webarchive.nationalarchives.gov.uk/201608 17104546/https://www.gov.uk/government/topical-events/eu-referendum, 17.06.2019.

GOV.UK (2016b), EU referendum outcome: PM statement, 24 June 2016: Prime Minister David Cameron made a statement in Downing Street on the outcome of the referendum on the UK's membership of the European Union, 24.06.2016, https://webarchive.nationalarchives.gov. uk/20160817104943/https://www.gov.uk/government/speeches/eu-referendum-outcome-pmstatement-24-june-2016, 19.06.2019.

Government of the Netherlands (2019), Brexit: where do we stand?, https://www.government.nl/topics/ brexit/brexit-where-do-we-stand, 18.06.2019.

Hauck \& Aufhäuser Privatbankiers AG (2019), Brexit-Folgen für den Alltag und auf Reisen. https:// www.hauck-aufhaeuser.com/fileadmin/News/190226_Brexit_Folgen.pdf, 29.06.2019.

HESA (2019), Higher Education Student Statistics: UK, 2017/18 - Where students come from and go to study, 17.01.2019, https://www.hesa.ac.uk/news/17-01-2019/sb252higher-education-student-statistics/location, 30.06.2019.

Hubble S., Bolton P. (2019), International and EU students in higher education in the UK FAQs, 20.03.2019, https://researchbriefings.parliament.uk/ResearchBriefing/Summary/CBP-7976, 29.06.2019.

Koszel B. (2018), Rola Niemiec w procesach decyzyjnych Unii Europejskiej w XXI wieku, Wydawnictwo Naukowe WNPiD UAM, Poznań.

KPMG (2017), Brexit basics: The Four Freedoms, https://assets.kpmg/content/dam/kpmg/xx/ pdf/2017/02/brexit-basics-the-four-freedoms.pdf, 17.06.2019.

Kraatz S. (2018), Free movement of workers, http://www.europarl.europa.eu/factsheets/en/sheet/41/ free-movement-of-workers, 01.07.2019.

Maciejewski M. (2018a), Free movement of goods, http://www.europarl.europa.eu/factsheets/en/ sheet/38/free-movement-of-goods, 01.07.2019.

Maciejewski M. (2018b), Freedom of establishment and freedom to provide services, http://www. europarl.europa.eu/factsheets/en/sheet/40/freedom-of-establishment-and-freedom-to-provideservices, 01.07.2019.

Rakić D., Dessimirova D. (2019), Free movement of capital, http://www.europarl.europa.eu/factsheets/ en/sheet/39/free-movement-of-capital, 01.07.2019. 
TEU (2012), 26.10.2012, Official Journal of the European Union, C 326, pp. 16-45.

TFEU (2012), 26.10.2012, Official Journal of the European Union, C 326, pp. 47-390.

Walker N. (2019), Brexit timeline: events leading to the UK's exit from the European Union, 23.05.2019, https://researchbriefings.parliament.uk/ResearchBriefing/Summary/CBP-7960, 19.06.2019.

www.parliament.uk (2019a), Stella Creasy MP, https://www.parliament.uk/biographies/commons/ stella-creasy/4088/biography, 09.07.2019.

www.parliament.uk (2019b), Votes and Proceedings, https://www.parliament.uk/business/publications/ business-papers/commons/votes-and-proceedings/, 20.07.2019.

Zoega G. (2016), On the causes of Brexit: Regional differences in economic prosperity and voting behaviour, 01.09.2016, https://voxeu.org/article/brexit-economic-prosperity-and-voting-behaviour, 19.06.2019.

\section{Brexit i jego skutki dla Niemiec z perspektywy ekonomicznej i społecznej}

\section{Streszczenie}

Pod koniec marca 2017 r., rząd brytyjski zainicjował procedurę prawną dotyczącą wystąpienia z Unii Europejskiej, rozpoczynając tym samym dwuletnie odliczanie do Brexitu. Jednakże, biorąc pod uwagę stan na sierpień 2019 r., ostateczny wynik negocjacji, jest nadal w toku. Niepewność wywołana przez Brexit w ciągu ostatnich lat wpływała negatywnie na gospodarkę Wielkiej Brytanii, np. wzrost gospodarczy.

Niniejsza praca ukazuje wpływ Brexitu na Niemcy z uwzględnieniem perspektywy ekonomicznej i społecznej. W naszych analizach rozróżniamy między efektami po ogłoszeniu Brexitu, a jego możliwymi skutkami. Uwzględniając perspektywę ekonomiczną, nasze analizy koncentrują się na czterech swobodach rynku wewnętrznego Unii Europejskiej. W perspektywie społecznej, nasze analizy skupiają się na mobilności, studiach i praktykach w Wielkiej Brytanii, transakcjach finansowych oraz prawach konsumentów. Za pomocą statystyk opisowych, bazując głównie na danych z Destatis i Eurostatu, przewidujemy następujące konsekwencje.

Biorąc pod uwagę perspektywę ekonomiczną, spodziewamy się negatywnych następstw, takich jak pogorszenie relacji handlowych między Wielką Brytanią a Niemcami, wpływających na zatrudnienie, w szczególności w sektorze motoryzacyjnym. Uwzględniając perspektywę społeczną, spodziewamy się także negatywnych konsekwencji, np. wynikających z podróżowania do Wielkiej Brytanii: rosnących kosztów podróży, opłat roamingowych, dodatkowego ubezpieczenia zdrowotnego. Wśród pozostałych obszarów, na które może wpływać Brexit wskazać należy studia i praktyki w Wielkiej Brytanii, transakcje finansowe oraz prawa konsumentów.

Slowa kluczowe: Brexit, konsekwencje, gospodarka, społeczeństwo, Niemcy 